\title{
PCP Site 2: A High Affinity MK-801-Insensitive Phencyclidine Binding Site
}

\author{
RICHARD B. ROTHMAN \\ Clinical Psychopharmacology Section, NIDA Addiction Research Center, \\ P.O. Box 5180, Baltimore, MD 21224
}

Received 4 February 1994; Accepted 14 March 1994

\begin{abstract}
ROTHMAN, R. B. PCP site 2: $A$ high affinity $M K$-801-insensitive phencyclidine binding site. NEUROTOXICOL TERATOL 16(4) 343-353, 1994. - Phencyclidine (PCP), a psychotomimetic drug with anticonvulsant and neuroprotective properties interacts with several central nervous system (CNS) macromolecules. These include cholinergic receptors, potassium channels, biogenic amine reuptake systems, the $N$-methyl-D-aspartate (NMDA) excitatory amino acid receptor, and sigma binding sites. The good correlation between the affinity of arylcycloalkylamines for high affinity PCP binding sites and their $\mathrm{ED}_{50}$ values for inhibition of $\left[{ }^{3} \mathrm{H}\right]$ dopamine uptake supports the notion that a PCP binding site associated with the transporter for the biogenic amines should be detectable in ligand binding studies. This article reviews data primarily from the author's labora-

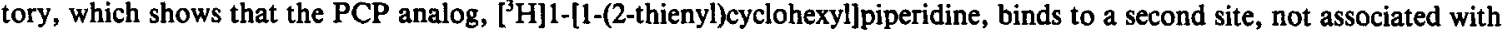
the NMDA receptor/ionophore complex, called PCP site 2. The ligand-selectivity of this binding site and the evidence that it is associated with the biogenic amine transporters are reviewed.
\end{abstract} (+)-5-methyl-10,11-dihydro-5H-dibenzo[a,d]cyclohepten-5,10-imine
Maleate
Dopamine transporter Serotonin transporter 1-[1-(2-thienyl)cyclohexyl]piperidine

PHENCYCLIDINE (PCP), a psychotomimetic drug with anticonvulsant and neuroprotective properties, interacts with several central nervous system (CNS) macromolecules. These include cholinergic receptors $(4,6)$ potassium channels $(7,16)$ biogenic amine reuptake systems (54), and the $N$-methyl-Daspartate (NMDA) excitatory amino acid receptor $(5,15)$ and sigma binding sites $(48,59)$.

Many reports indicate that the pharmacologically relevant actions of PCP are mediated via receptors associated with the NMDA receptor $(20,24,25,47)$. However, in vivo effects of PCP which are mediated via the NMDA receptor such as its anticonvulsant (26) and neuroprotective (43) effects, occur at the similar dose ranges as effects of PCP which are mediated by blockade of dopamine (DA) reuptake, such as hypothermia (32), decreased release of prolactin $(30,31)$, as well as increases in extracellular DA as measured by in vivo microdialysis (11).

These data and the good correlation between the affinity of arylcycloalkylamines for high affinity PCP binding sites and their $\mathrm{ED}_{50}$ values for inhibition of DA reuptake $(21,54)$ supports the notion that a PCP binding site associated with the transporter for the biogenic amines should be detectable in ligand binding studies. Published studies report either a single high affinity binding site $(34,64)$ or multiple binding sites $(13,28,53,56)$. In support of the two-site model, a recent studies from our laboratory, using membranes prepared from guinea pig brain demonstrated and characterized a second high affinity PCP binding site (site 2$)(2,3,36,41,42)$. The purpose of this article is to review these data.

\section{EVIDENCE THAT $\left[{ }^{3} \mathrm{H}\right] \mathrm{TCP}$ LABELS TWO BINDING SITES}

Our initial studies tested the hypothesis that $\left[{ }^{3} \mathrm{H}\right] 1-[1-(2$ thienyl)cyclohexyl]piperidine $\left(\left[{ }^{3} \mathrm{H}\right] \mathrm{TCP}\right)$ labeled more than one binding site in membranes prepared from guinea pig brain (41). Quantitative ligand binding studies conducted according to the principles of "binding surface analysis" (39), readily resolved two binding sites. As shown in Fig. 1, the initial data set examined the interaction of TCP, (+)-5-methyl-10,11-dihydro-5H-dibenzo[a,d]cyclohepten-5,10-imine maleate $\{(+)$ MK-801\}, (+)-SKF10,047 and N-[1-(2-benzo(b)thiophenyl)cyclohexyl\}piperidine (BTCP) with $\left[{ }^{3} \mathrm{H}\right] \mathrm{TCP}$ binding sites (Fig. 1). Nonlinear least squares curve fitting with MLAB indicated that $\left[{ }^{3} \mathrm{H}\right] \mathrm{TCP}$ labeled two sites with high affinity at which (+)-MK-801 had high affinity $(\mathrm{Ki}=3.2 \mathrm{nM}, \mathrm{PCP}$ site 1) and much lower affinity ( $\mathrm{Ki}=5200 \mathrm{nM}, \mathrm{PCP}$ site 2$)$. On the other hand, BTCP, which is a high affinity inhibitor of DA reuptake (55) had Ki values of $>1 \mathrm{mM}$ for PCP site 1 and $1083 \mathrm{nM}$ for PCP site 2, indicating that it bound with low affinity to but with a high degree of selectivity for PCP site 2 .

Kinetic experiments served to further distinguish the two 

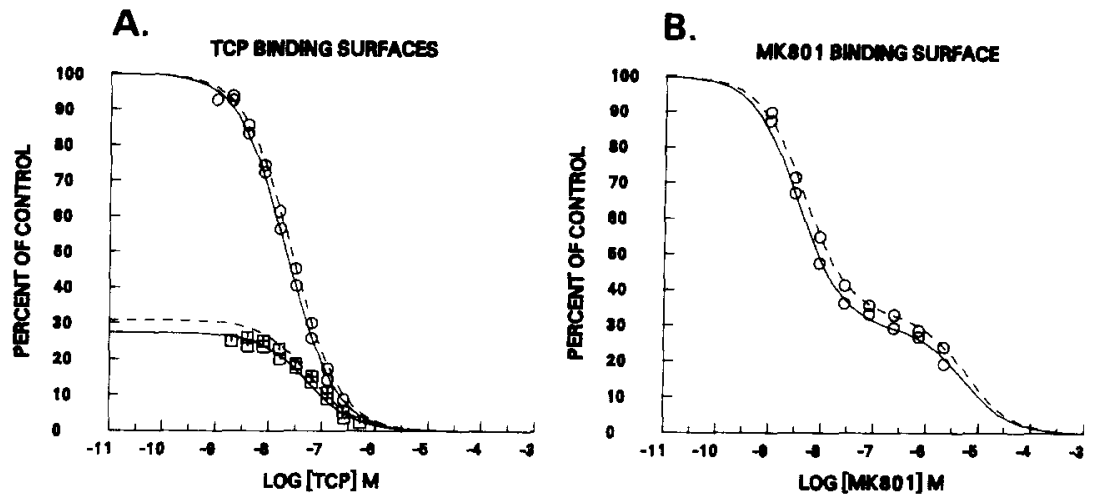

C.
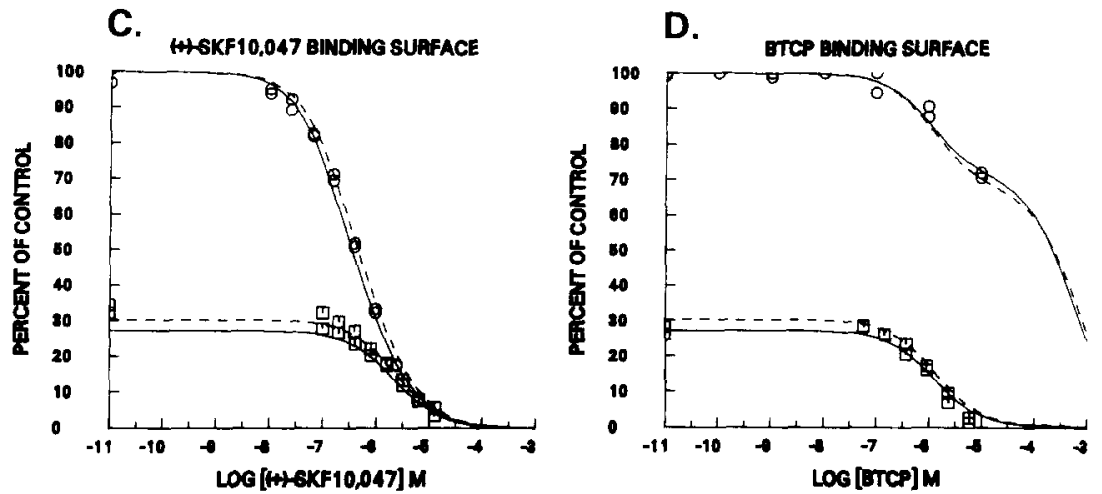

FIG. 1. Characterization of $\left[{ }^{3} \mathrm{H}\right] \mathrm{TCP}$ binding sites. (A) TCP and (t)-MK-801 Binding Surfaces. Displacement of $1.05 \mathrm{nM}$ (solid lines) and $5.35 \mathrm{nM}\left[{ }^{3} \mathrm{H}\right] \mathrm{TCP}$ (dashed lines) by eight concentrations of TCP in the absence (circles) and presence (squares) of $1 \mu \mathrm{M}$

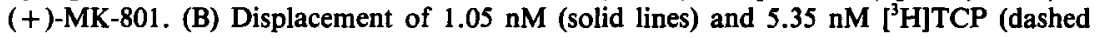
lines) by eight concentrations of (+)-MK-801. The specific binding at $1.05 \mathrm{nM}$ and 5.35 nM $\left[{ }^{3} \mathrm{H}\right] \mathrm{TCP}$ was 85.8 and $349 \mathrm{fmol} / \mathrm{mg}$ protein, respectively. Each point is the mean of three experiments, which differed by less than $10 \%$. The entire set of data (54 points) were fit to a one site binding model. The sum-of-squares (SS) was 1.00 . Fitting the data to a two-site binding model resulted in a highly significant $(F$ test, $p<0.001)$ reduction in the SS to 0.069 . The best-fit parameter estimates reported in Table 1 generated the lines shown in the figure illustrating the goodness of fit. (C) (+)-SKF10,047 and BTCP Binding Surfaces. Displacement of $0.91 \mathrm{nM}$ (solid lines) and $4.64 \mathrm{nM}\left[{ }^{3} \mathrm{H}\right] \mathrm{TCP}$ (dashed lines) by concentrations of (+)-SKF10,047 in the absence (circles) and presence (squares) of $500 \mathrm{nM}$ (+)-MK-801. Each point is the mean of two experiments, which differed by less than $10 \%$. The $B_{\max }$ and $K_{\mathrm{d}}$ values of TCP and (+)-MK-801 were fixed to the values reported in Table 1 of (41) and the entire set of data (36 points) fit to a one site model (SS $=0.133$ ). Fitting the data to a two-site model resulted in a highly significant decrease in the SS to 0.021 $(p<0.001, F$ test). The best-fit parameter values of the two-site model were reported in Table 1 of (41) and generated the lines in the figure. Similar experiments were conducted with PCP, (-)-cyclazocine and etoxadrol. (D) Displacement of $0.94 \mathrm{nM}$ (solid lines) and $4.29 \mathrm{nM}\left[{ }^{3} \mathrm{H}\right] \mathrm{TCP}$ (dashed lines) by concentrations of BTCP in the absence (circles) and presence (squares) of $500 \mathrm{nM}(+)-M K-801$. The data were fit to a two-site model as described for $\mathrm{C}$ and the results reported in Table 1 .

binding sites (41). Magnesium and the excitatory amino acid neurotransmitter glutamate are well known modulators of the PCP binding sites associated with the NMDA receptor (27). As shown in Fig. 2, the addition of $\mathrm{Mg}^{++}(100 \mu \mathrm{M})$ greatly accelerated the dissociation of $\left[{ }^{3} \mathrm{H}\right] \mathrm{TCP}$ prebound to PCP site 1. This effect was reversed by the addition of the competitive NMDA antagonist, 2-amino-7-phosphonoheptanoic acid (AP7, $100 \mu \mathrm{M}$ ), and the effect of AP7 was reversed by the addition of L-glutamate. As reported in Fig. 3, L-glutamate reversed the AP7 effect much more effectively than did Dglutamate. These modulators did not effect the dissociation of $\left.{ }^{3} \mathrm{H}\right] \mathrm{TCP}$ from PCP site 2 . Viewed collectively, these data support the hypothesis that whereas PCP site 1 is associated with the NMDA receptor, PCP site 2 is not. Other studies demonstrated that the modulation of $\left[{ }^{3} \mathrm{H}\right] \mathrm{TCP}$ binding to PCP site 1 by AP7 and glutamate was best described by an allosteric rather than a steric hindrance model (40).

\section{LIGAND-SELECTIVITY PATTERNS OF PCP SITES 1 AND 2}

The observation described above that the high affinity DA reuptake inhibitor BTCP was highly selective for PCP site 2 (41) prompted additional ligand selectivity studies (42). As reported in Table 1 , the selectivity of these agents for site 2 

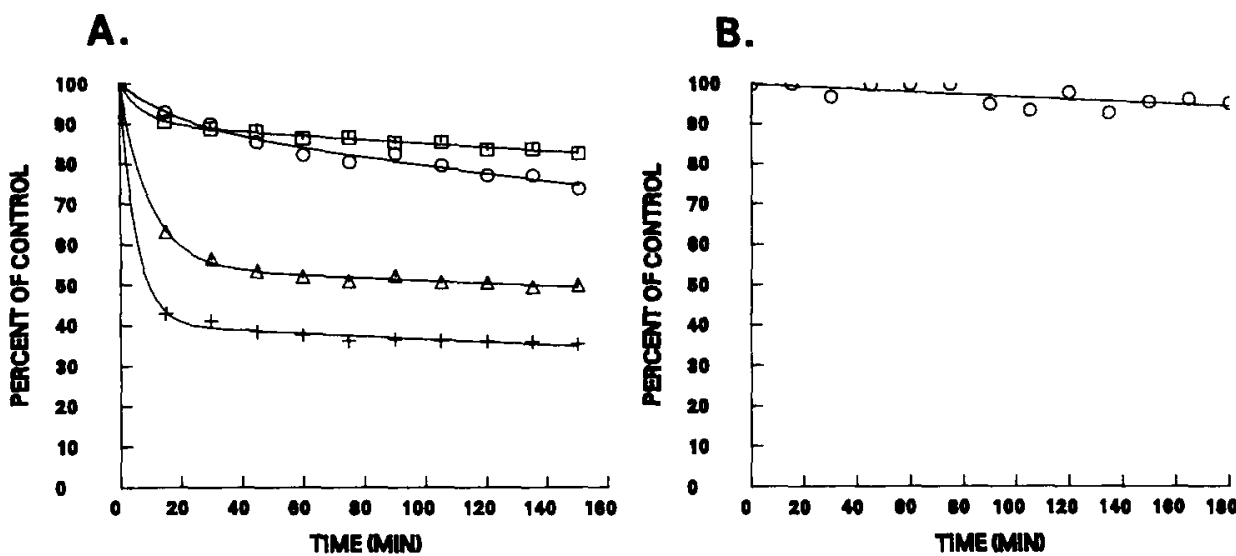

FIG. 2. Dissociation of $\left[{ }^{3} \mathrm{H}\right] \mathrm{TCP}$ from PCP site 1 and PCP site 2. Dissociation time courses were generated to examine the ability of agents $(100 \mu \mathrm{M})$ to alter $\left[{ }^{3} \mathrm{H}\right] \mathrm{TCP}$ dissociation rates as described in the Method section. Each point is the mean of three independent experiments, which differed by less than $10 \%$. (A) Dissociation of $\left[{ }^{3} \mathrm{H}\right] \mathrm{TCP}$ From Site 1 . The dissociation of $\left[{ }^{3} \mathrm{H}\right] \mathrm{TCP}$ from site 1 was calculated as described in (41). The data of the control curve (circles), $\mathrm{Mg}^{++}$(triangles), $\mathrm{Mg}^{++} / \mathrm{AP7}$ (squares) and $\mathrm{Mg}^{++} / \mathrm{AP7} /$ Glutamate $(+)$ were not adequately described by a one component dissociation model so they were fit to a two component dissociation model. (B) Dissociation of $\left[{ }^{3} \mathrm{H}\right]$ TCP From Site 2. The dissociation of $\left[{ }^{3} \mathrm{H}\right] \mathrm{TCP}$ from site 2 was calculated as described in (41). The data of this condition was fit to a one component dissociation model with a resulting rate constant of $0.00033 \pm 0.000054 \mathrm{~min}-1$. This parameter was used to draw the line in the figure.

ranged from 0.00068 for $( \pm)$-5-[2-aminoethyl]-10,11-dihydro$5 \mathrm{H}$-dibenzo[a,d]cyclohepten-5,10-imine-HCl (JMII179b) to greater than 1473 for the noradrenergic reuptake inhibitor xylamine. In general, agents which effect the reuptake mechanisms of the biogenic amines were moderately to highly selective for site 2. Their $\mathrm{Ki}$ values at $\mathrm{PCP}$ site 2 ranged from $183 \mathrm{nM}$ for benztropine to $6383 \mathrm{nM}$ for (+)-cocaine. Both enantiomers of cocaine had about the same affinity for site 2. There did not appear to be any discernible relationship between the selectivity of a reuptake inhibitor among the biogenic amines and their $\mathrm{Ki}$ value at site 2 . For example, fluoxetine (5-HT-selective), bupropion (DA-selective), and mazindol (NE- and DA-selective) all had Ki values of about $1000 \mathrm{nM}$. Agents related to MK-801 (tiletamine and ( \pm )-5-bromomethyl-10,11 - dihydro- $5 \mathrm{H}$-dibenzo [a,d] cyclohepten - 5,10-imineoxalate $\{$ JMII141c\}) had moderate affinity for site 1 and were relatively selective for site 1 . The affinity of benztropine for site $2(\mathrm{Ki}=183 \mathrm{nM})$ was strikingly high. Ketamine, which is a very weak inhibitor of DA reuptake was moderately selective for site 1.

These data indicate that a diverse range of drugs which possess the ability to inhibit the reuptake of the biogenic amines bind weakly but with a high degree of selectivity to PCP site 2 . These drugs include pargyline, $\mathrm{D}$-amphetamine, clomipramine (CMI), fluoxetine, mazindol, 1-[2-[bis(4-fluorophenyl)methoxy]ethyl]-4-[3-phenylpropyl]piperazine (GBR12909), benztropine, xylamine, desipramine, bupropion, and BTCP. These agents all have varying degrees of selectivity in regard to their ability to inhibit the reuptake of $\left[{ }^{3} \mathrm{H}\right] \mathrm{DA},\left[{ }^{3} \mathrm{H}\right] 5-\mathrm{HT}$ and $\left.{ }^{3} \mathrm{H}\right] \mathrm{NE}$.

As just mentioned, it is noteworthy that although these drugs are very selective for PCP site 2 , they have lower affinity than would be expected on the basis of their $\mathrm{IC}_{50}$ values for inhibition of the reuptake mechanism under physiological conditions. The simplest explanation for this is that whereas physiological concentrations of $\mathrm{NaCl}$ are required to detect high affinity inhibition of reuptake, $\mathrm{NaCl}$ inhibits $\left[{ }^{3} \mathrm{H}\right] \mathrm{TCP}$ binding $(2,57)$. Thus, the optimal assay conditions for measuring biogenic amine transporter binding sites are poor assay conditions for measuring $\left[{ }^{3} \mathrm{H}\right] \mathrm{TCP}$ site 2 .

In view of the extensive evidence that PCP blocks voltagedependent $\mathrm{K}^{+}$channels in central neurons $(8,16)$, we examined the interaction of various diverse $\mathrm{K}^{+}$channel blocking agents with PCP sites 1 and 2 (42). As reported in Table 2, of the compounds investigated, quinine, a blocker of $\mathrm{Ca}^{2+}$-dependent and other $\mathrm{K}^{+}$channels (14), was the most potent, displacing $\left[{ }^{3} \mathrm{H}\right] \mathrm{TCP}$ from either site with an $\mathrm{IC}_{50}$ of about $20 \mu \mathrm{M}$. Glyburide, a selective blocker of ATP-sensitive $\mathrm{K}^{+}$channels, and 4-AP, a relatively selective blocker of A-type (fast inactivating) voltage-dependent $\mathrm{K}^{+}$channels (38) were next in potency. Both of these drugs were active in the range of hundreds of micromolar. The effective concentrations of glyburide were higher than those that block ATP-sensitive $\mathrm{K}^{+}$channels in neurons (33) whereas 4-AP was active at concentrations that were similar or somewhat lower than those that block Acurrents. TEA, an antagonist of delayed rectifier and some $\mathrm{Ca}^{2+}$-dependent $\mathrm{K}^{+}$channels, was the only $\mathrm{K}^{+}$channel blocker tested which exhibited selectivity among the two PCP sites. Binding to site 2 was inhibited with an $\mathrm{IC}_{50}$ of about 100 $\mu \mathrm{M}$, whereas at site 1 the $\mathrm{IC}_{50}$ was 120 -fold higher. Finally, apamin and charybdotoxin, selective antagonists of $\mathrm{Ca}^{2+}$. dependent $\mathrm{K}^{+}$channels (charybdotoxin also blocks certain voltage-dependent $\mathrm{K}^{+}$channels; see, e.g., ref. 60 ) failed to affect binding to either site 1 or 2 at concentrations that were substantially higher than those that block $\mathrm{K}^{+}$currents in physiological recordings.

All of the $\mathrm{K}^{+}$channel blockers except apamin and charybdotoxin interacted to some extent with both of the $\left[{ }^{3} \mathrm{H}\right] \mathrm{TCP}$ binding sites at concentrations within an order of magnitude or so of the concentrations that antagonize $\mathrm{K}^{+}$currents in intact cells. In most cases, the affinities for the two sites was similar. However, TEA was 120 -fold selective for site 2 . This 


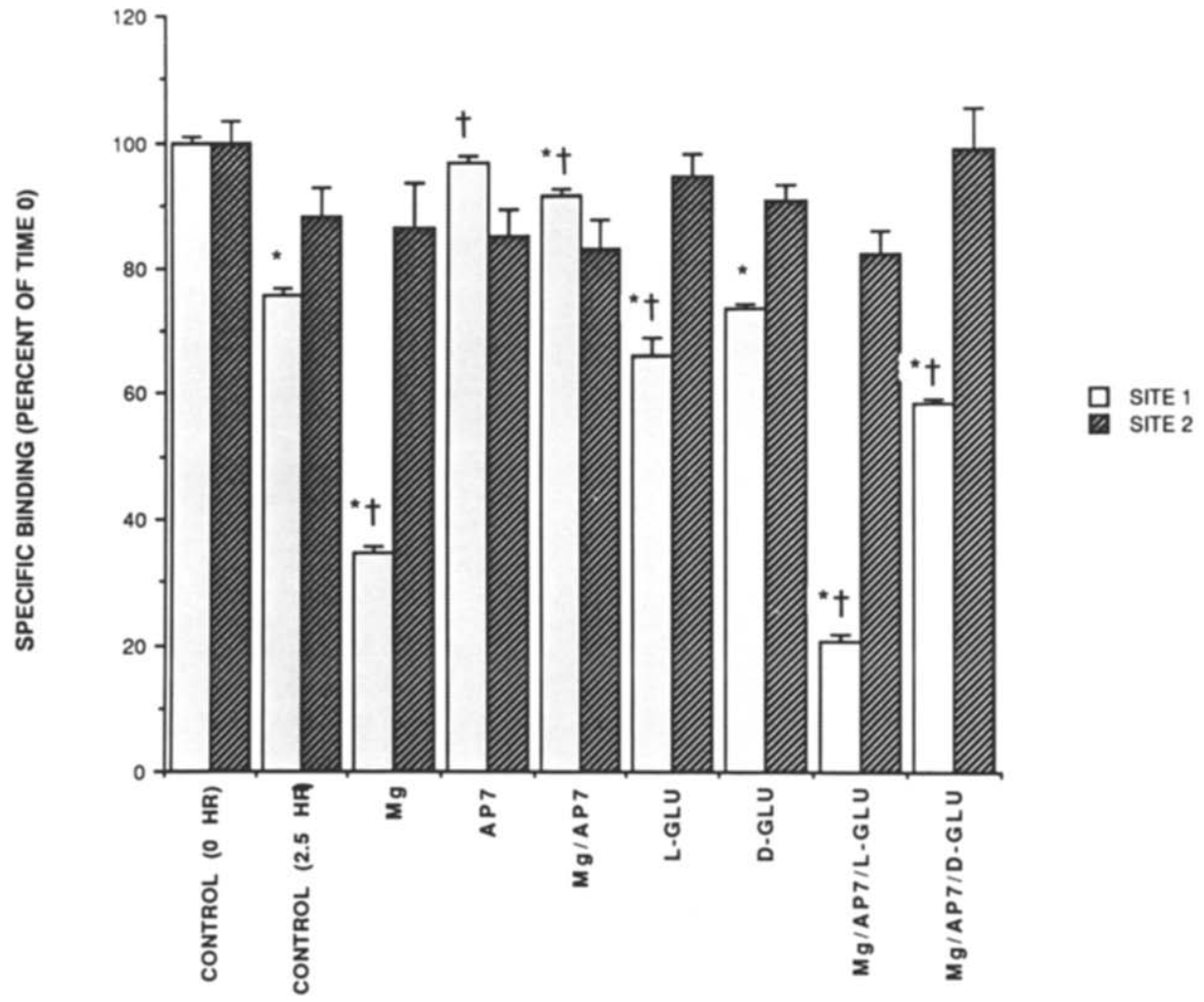

FIG. 3. Effect of agents on dissociation of $\left.\left.{ }^{3} \mathrm{H}\right] \mathrm{TCP} .{ }^{3} \mathrm{H}\right] \mathrm{TCP}(5 \mathrm{nM})$ was incubated with membranes at $0^{\circ} \mathrm{C}$ for $2 \mathrm{~h}$ in the absence of drug (Condition 1), in the presence of $1 \mu \mathrm{M}(+)-\mathrm{MK}-801$ (Condition 2), and in the presence of $1 \mu \mathrm{M}$ TCP (Condition 3). The incubation was terminated by centrifugation at $27000 \times \mathrm{g}$ for $15 \mathrm{~min}$. To initiate dissociation, the pellets were resuspended in the same volume of ice-cold $5 \mathrm{mM}$ Tris $\mathrm{HCl} \mathrm{pH} 8.2$ buffer. One $\mathrm{ml}$ aliquots were distributed to test tubes prefilled with various agents (all at a final concentration of $100 \mu \mathrm{M}$ ). Control conditions received no agents. A time 0 point was filtered immediately. All other points were filtered $2.5 \mathrm{~h}$ after the addition of membranes. Each value is the mean \pm SD of three determinations and are expressed as a percent of the time 0 point. ${ }^{*} p<0.01$ when compared to the time 0 point. ${ }^{*} p<0.01$, when compared to the $2.5 \mathrm{~h}$ control. The entire experiment was repeated with similar results (ANOVA analysis).

is of interest since TEA, in contrast to other conventional $\mathrm{K}^{+}$ channel blockers is a relatively selective antagonist of delayed rectifier type voltage-dependent $\mathrm{K}^{+}$channels and only blocks A-type $\mathrm{K}^{+}$channels at very high concentrations $(44,49,50)$. Similarly, at moderate concentrations, PCP also selectively blocks delayed rectifier $\mathrm{K}^{+}$channels and only blocks A-type voltage-dependent $\mathrm{K}^{+}$channels at 10 -fold higher concentrations $(8,16)$. These data indicate that the ligand-selectivity pattern of PCP site 2 may have some similarity to the PCP blocking site on the neuronal delayed rectifier $\mathrm{K}^{+}$channel.

\section{OCCURRENCE OF PCP SITE 2 IN DIFFERENT SPECIES}

Membranes were prepared from selected brain regions of various species and the occurrence of PCP site 1 and PCP site 2 determined using $0.5 \mu \mathrm{M}(+)-\mathrm{MK}-801$ to block the binding of $\left[{ }^{3} \mathrm{H}\right] \mathrm{TCP}$ to site 1 . Site 2 was considered undetected if the binding in the presence of $0.5 \mu \mathrm{M}(+)$-MK-801 was not significantly different from the nonspecific binding. As reported in Table 3, rabbit, sheep, chicken, guinea pig, mouse, and pig brain had varying levels of PCP site 2 . It is important to note that the values reported in Table 3 are not $\boldsymbol{B}_{\max }$ values but are the specific binding observed with $2 \mathrm{nM}\left[{ }^{3} \mathrm{H}\right] \mathrm{TCP}$. Because rat brain had no detectable levels of PCP site 2, various preparations of rat brain were examined in greater detail for the occurrence of PCP site 2 . As described in Table $4,\left[{ }^{3} \mathrm{H}\right] \mathrm{TCP}$ binding to membranes prepared from whole brain and caudate was well described by one site binding models.

These data clearly indicate that most species, with the exception of the rat, have detectable levels of PCP site 2. The inability to detect PCP site 2 in rat brain prompted the authors to use membrane preparations which would be enriched with reuptake binding sites, such as lysed-P2 membranes (prepared from nerve terminals) and caudate membranes which are enriched with the DA reuptake complex. However, even with these membrane preparations there was no detectable PCP site 2. Although PCP clearly inhibits the reuptake of biogenic amines in rat brain, the reason why this site can not be labeled in vitro with $\left[{ }^{3} \mathrm{H}\right] \mathrm{TCP}$ remains enigmatic. One possibility is that the absence of sodium in this assay condition may contribute to the apparent absence of PCP site 2 which is thought to be associated with the reuptake system (a process that requires the presence of sodium ion). Alternatively, it may be that the affinity of $\left[{ }^{3} \mathrm{H}\right] \mathrm{TCP}$ for PCP site 2 in rat brain is 
TABLE 1

LIGAND-SELECTIVITY STUDY: GUINEA PIG BRAIN

\begin{tabular}{lccc}
\hline Drug & Site $1(\mathrm{Ki}, \mathrm{nM} \pm \mathrm{SD})$ & Site $2(\mathrm{Ki}, \mathrm{nM} \pm \mathrm{SD})$ & Site 1/Site 2 \\
\hline Pargyline & $>1 \mathrm{mM}$ & $3643 \pm 446$ & $>274$ \\
D-Amphetamine & $80501 \pm 4912$ & $959 \pm 358$ & 41.1 \\
Clomipramine & $63437 \pm 8787$ & $4684 \pm 1925$ & 13.5 \\
(-)-Cocaine & $282362 \pm 25011$ & $6014 \pm 903$ & 46.9 \\
(+)-Cocaine & $>1 \mathrm{mM}$ & $6383 \pm 1292$ & $>157$ \\
Fluoxetine & $264590 \pm 34880$ & $929 \pm 252$ & 285 \\
Mazindol & $218993 \pm 43411$ & $919 \pm 413$ & 238 \\
GBR12909 & $102118 \pm 14000$ & $3167 \pm 1167$ & 32 \\
Benztropine & $15689 \pm 28442$ & $183 \pm 124$ & 857 \\
Xylamine & $>1 \mathrm{mM}$ & $679 \pm 128$ & $>1473$ \\
Desipramine & $11954 \pm 1013$ & $2137 \pm 631$ & 5.6 \\
Nomifensine & $139456 \pm 11071$ & $2604 \pm 512$ & 54 \\
Bupropin & $>1 \mathrm{mM}$ & $704 \pm 156$ & $>1420$ \\
BTCP & $>1 \mathrm{mM}$ & $1083 \pm 167$ & $>923$ \\
Ketamine & $813 \pm 50$ & $4702 \pm 1056$ & 0.17 \\
Tiletamine & $79.3 \pm 3.2$ & $1394 \pm 194$ & 0.057 \\
JMII141C & $70 \pm 4.0$ & $9298 \pm 1706$ & 0.0075 \\
JMII7B & $12.7 \pm 0.8$ & $18557 \pm 4023$ & 0.00068 \\
PCA(1) & $1262 \pm 162$ & $1327 \pm 514$ & 1.05 \\
PPA(37) & $6463 \pm 319$ & $3200 \pm 490$ & 2.0 \\
\hline
\end{tabular}

Data reported in (42) are summarized. Abbreviations are: 1-phenylcyclohexylamine-HCl (PCA-1), 1-phenylcyclopentyllamine-HCl (PPA-37), ( \pm )-5-bromomethyl-10,11-dihydro-5H-dibenzo[a,d]cyclohepten-5, 10-imine-oxalate (JMII141c) and $( \pm)$-5-[2-aminoethyl]-10,11-dihydro-5H-dibenzo[a,d]cycloheptan-5,10-imine$\mathrm{HCl}$ (JMII179b). 1-[2-[bis(4-fluorophenyl)methoxy]ethyl]-4-[3-phenylpropyl]piperazine (GBR12909). These compounds were synthesized in the Laboratory of Medicinal Chemistry, NIDDK (52).

lower than in other species, making it correspondingly more difficult to detect. Nevertheless, it is important to point out that the inability to detect PCP site 2 in rat brain does not mean that it does not exist.

The ligand-selectivity pattern of PCP sites 1 and 2 in human brain (3) was qualitatively the same as observed with

TABLE 2

INTERACTION OF POTASSIUM CHANNEL BLOCKERS WITH PCP SITE 1 AND 2

\begin{tabular}{lcc}
\hline & \multicolumn{3}{c}{$\mathrm{IC}_{s 0} \pm \mathrm{SD}$} \\
\cline { 2 - 3 } Drug & PCP Site 1 & PCP Site 2 \\
\hline Glyburide & $>110 \mu \mathrm{M}$ & $224 \pm 76 \mu \mathrm{M}$ \\
& {$[0.70 \pm 0.13]$} & \\
Quinine & $18.7 \pm 2.9 \mu \mathrm{M}$ & $17.1 \pm 1.6 \mu \mathrm{M}$ \\
& {$[0.59 \pm 0.06]$} & {$[0.59 \pm 0.04]$} \\
TEA & $11.6 \pm 0.05 \mathrm{mM}$ & $96.4 \pm 18 \mu \mathrm{M}$ \\
& {$[0.89 \pm 0.003]$} & {$[0.59 \pm 0.08]$} \\
4-AP & $390 \pm 9 \mu \mathrm{M}$ & $276 \pm 34 \mu \mathrm{M}$ \\
& {$[1.29 \pm 0.04]$} & {$[0.55 \pm 0.04]$} \\
PCP & $178 \pm 9 \mathrm{nM}$ & $287 \pm 21 \mathrm{nM}$ \\
& {$[1.06 \pm 0.06]$} & {$[0.69 \pm 0.05]$} \\
\hline
\end{tabular}

These data are taken from (42). The values in the brackets are the slope factors. Each value is reported \pm the SD. Apamin $(1 \mu \mathrm{M})$ and charybdotoxin $(50 \mathrm{nM})$ did not alter $\left.{ }^{3} \mathrm{H}\right] \mathrm{TCP}$ binding to either PCP site 1 or PCP site 2. guinea pig brain membranes (Table 1). As shown in Table 5 , there were interesting quantitative differences. The $K_{d}$ values of TCP for site 2 were higher in human brain (197 $\mathrm{nM})$ than for guinea pig brain ( $46 \mathrm{nM})$, and the $\mathrm{Ki}$ value of $(+)-\mathrm{MK}-801$ for site 1 was lower in guinea pig brain (3.2 $\mathrm{nM}$ ) than in human brain (8.9 $\mathrm{nM})$. Interestingly, although in guinea pig whole brain membranes PCP sites 1 and 2 are present at about equal densities (41); in human brain cortex membranes site 2 is the more abundant binding site.

\section{EVIDENCE THAT PCP SITE 2 IS ASSOCIATED WITH THE BIOGENIC AMINE TRANSPORTERS}

Several lines of evidence support the hypothesis that PCP site 2 is associated with biogenic amine reuptake carriers. First, high affinity serotonergic (fluoxetine) and dopaminergic (GBR12909 and BTCP) reuptake inhibitors bind relatively selectively to PCP site 2 . The reason for their low affinity interaction with PCP site 2, as just mentioned, probably relates to the absence of $\mathrm{NaCl}$ in the assay medium. Second, PCP, which inhibits the reuptake of DA and serotonin (46) has high affinity for site 2 whereas (+)-MK-801 which is a very weak DA reuptake blocker (47) binds selectively to site 1 .

A third line of evidence comes from wash-resistant inhibition experiments. In these studies, membranes are incubated with various concentrations of test drugs extensively washed by repeated centrifugation and resuspension and finally assayed. As shown in Fig. 4 for human brain membranes, fluoxetine, GBR12909 and BTCP produce wash-resistant inhibition of $\left[{ }^{3} \mathrm{H}\right] \mathrm{TCP}$ binding to site 2 (Fig. 4). As described in recent publications $(37,51)$, there are several mechanisms 
TABLE 3

PCP SITE 1 AND SITE 2 IN BRAIN MEMBRANES PREPARED FROM DIFFERENT SPECIES

\begin{tabular}{lccccc}
\hline & \multicolumn{5}{c}{ Fmol/mg Protein \pm SD } \\
\cline { 2 - 6 } & Total & $(+)$-MK-801 & $\begin{array}{c}\text { Nonspecific } \\
\text { Binding }\end{array}$ & Site 1 & Site 2 \\
\hline Rabbit caudate & $301 \pm 49$ & $38 \pm 2^{*}$ & $31 \pm 1$ & 263 & 7 \\
Rabbit hippocampus & $657 \pm 11$ & $86 \pm 9^{*}$ & $40 \pm 1$ & 571 & 46 \\
Rabbit cortex & $422 \pm 14$ & $26 \pm 6$ & $19 \pm 3$ & 396 & 0 \\
Sheep caudate & $382 \pm 8$ & $80 \pm 7^{*}$ & $43 \pm 1$ & 302 & 37 \\
Sheep hippocampus & $237 \pm 13$ & $26 \pm 2$ & $21 \pm 1$ & 211 & 0 \\
Sheep cortex & $206 \pm 18$ & $63 \pm 3^{*}$ & $1 \pm 0.9$ & 143 & 62 \\
Chicken brain & $317 \pm 17$ & $26 \pm 3$ & $19 \pm 4$ & 291 & 0 \\
Guinea pig caudate & $483 \pm 18$ & $95 \pm 16^{*}$ & $52 \pm 2$ & 388 & 43 \\
Guinea pig hippocampus & $758 \pm 21$ & $138 \pm 17^{*}$ & $59 \pm 0.5$ & 620 & 79 \\
Mouse brain & $595 \pm 1$ & $82 \pm 5^{*}$ & $46 \pm 2$ & 513 & 36 \\
Pig caudate & $267 \pm 27$ & $51 \pm 5^{*}$ & $36 \pm 1$ & 216 & 15 \\
Pig hippocampus & $252 \pm 25$ & $66 \pm 11^{*}$ & $5 \pm$ & 186 & 61 \\
Pig cortex & $185 \pm 17$ & $9 \pm 0.9$ & $8 \pm 0.5$ & 176 & 0 \\
\hline
\end{tabular}

These data are taken from (3). Membranes were prepared from the brains of different mammalian species and assayed for $\left[{ }^{3} \mathrm{H}\right] \mathrm{TCP}$ binding in the absence (total binding) or presence of $500 \mathrm{nM}$ (+)-MK-801 (site 1 blocked) or $10 \mu \mathrm{M}$ TCP (nonspecific binding). The observed level of binding (fmol/mg protein) for all three conditions are reported above (mean $\pm \mathrm{SD}, n=3$ ). $\left[{ }^{3} \mathrm{H}\right] \mathrm{TCP}$ binding to site 1 was calculated as total binding minus the binding in the presence of $500 \mathrm{nM}(+)-\mathrm{MK}-801$. If the binding in the presence of $500 \mathrm{nM}(+)-\mathrm{MK}-801$ was statistically different from the nonspecific binding $\left(p<0.05\right.$, ANOVA with post-hoc Scheffé $F$ test), then $\left[{ }^{3} \mathrm{H}\right] \mathrm{TCP}$ binding to site 2 was calculated as binding in the presence of $500 \mathrm{nM}(+)-\mathrm{MK}-801$ minus the nonspecific binding. Please note that the values reported are not $B_{\max }$ values.

shown in Table 6, which can explain the phenomenon of washresistant inhibition.

The trivial explanation is that residual drug not removed by the wash procedure acts as a competitive inhibitor of binding. Because a membrane suspension is composed of an aqueous phase (the buffer) and a lipid phase (the membranes), the residual drug may be present in either the aqueous phase (mechanism 1) or the lipid phase (mechanism 2) or both.

TABLE 4

['H]TCP BINDING PARAMETERS IN DIFFERENT PREPARATIONS OF RAT BRAIN

\begin{tabular}{lrrr}
\hline & Whole Rat Brain & Rat lysed P2 & Rat Caudate \\
\hline $\begin{array}{l}B_{\max } \\
(\mathrm{fmol} / \mathrm{mg} \text { protein) }\end{array}$ & $1175 \pm 34$ & $1171 \pm 34$ & $972 \pm 50$ \\
$\begin{array}{l}\mathrm{TCP} \\
\left(\mathrm{K}_{\mathrm{d}}, \mathrm{nM}\right) \\
(+)-\mathrm{MK}-801\end{array}$ & $7 \pm 0.2$ & $8.8 \pm 0.3$ & $5.4 \pm 0.4$ \\
$\begin{array}{l}\left(\mathrm{K}_{\mathrm{d}}, \mathrm{nM}\right) \\
(-)-\mathrm{Cyclazocine} \\
\left(\mathrm{K}_{\mathrm{d}}, \mathrm{nM}\right)\end{array}$ & $176 \pm 4$ & $260 \pm 5$ & $119 \pm 6$ \\
\hline
\end{tabular}

These data are from (3). Binding surfaces were generated by displacing two concentrations of $\left[{ }^{3} \mathrm{H}\right] \mathrm{TCP}(1$ and $5 \mathrm{nM})$ each by eight concentrations of TCP, (-)-cyclazocine, and (+)-MK-801. Each point was the mean of two points which differed by less than $10 \%$. The best-fit parameters ( \pm SEM) of the one site binding model are reported. Fitting the data to a two-site binding model did not improve the goodness-of-fit.
Alternatively, the wash-resistant inhibitor might be tightly bound to the binding site of interest over the time course of the experiment. In the simplest of the tight-binder scenarios, occupation of the binding site by the wash-resistant inhibitor precludes labeling of the site by the $\left[{ }^{3} \mathrm{H}\right]$ ligand (mechanism 3 ). This would produce a decrease in the $B_{\max }$ of the target binding site. In a more complex scenario, the wash-resistant inhibitor binds to a different binding site or to a domain of the binding

TABLE 5

LIGAND-SELECTIVITY STUDY OF $\left[{ }^{3} \mathrm{H}\right]$ TCP BINDING SITES IN HUMAN BRAIN

\begin{tabular}{lrc}
\hline Drug & Site $1\left(\mathrm{~K}_{\mathrm{d}}, \mathrm{nM}\right)$ & \multicolumn{1}{c}{ Site $2\left(\mathrm{~K}_{\mathrm{d}}, \mathrm{nM}\right)$} \\
\hline (+)-MK-801 & $8.9 \pm 0.2$ & $11367 \pm 996$ \\
TCP & $19.8 \pm 0.4$ & $197 \pm 8$ \\
PCP & $43.8 \pm 2$ & $154 \pm 14.5$ \\
Dexoxadrol & $92 \pm 3$ & $1234 \pm 99$ \\
Tiletamine & $93 \pm 3$ & $17050 \pm 2700$ \\
Ketamine & $831 \pm 30$ & $59388 \pm 8674$ \\
GBR12909 & $30925 \pm 1403$ & $6841 \pm 54$ \\
BTCP & $46436 \pm 2924$ & $2102 \pm 229$ \\
Benztropine & $78179 \pm 1369$ & $2338 \pm 82$ \\
Bupropion & $101239 \pm 4812$ & $37519 \pm 49203$ \\
Fluoxetine & $106402 \pm 12497$ & $1677 \pm 328$ \\
(-)cocaine & $26739 \pm 11574$ & $423055 \pm 48265$ \\
\hline
\end{tabular}

These data are from (3). The best-fit parameter estimates ( \pm SEM) of various drugs for the two PCP binding sites are reported. The $B_{\max }$ values for sites 1 and 2 were 492 and 2038 fmole/mg protein, respectively. 

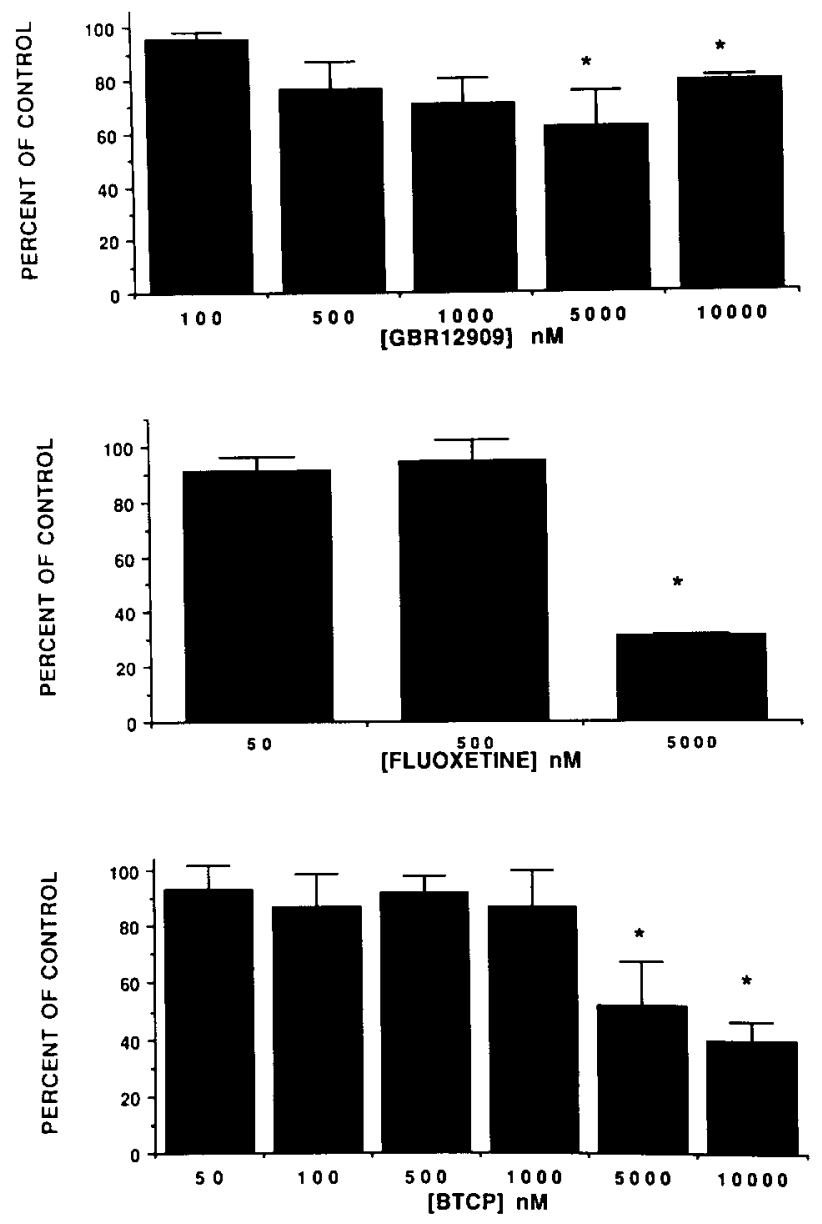

FIG. 4. Wash-resistant inhibition of $\left[{ }^{3} \mathrm{H}\right] \mathrm{TCP}$ binding to PCP site 2 . Human cortical membranes were preincubated with GBR12909 (Panel A), fluoxetine (Panel B), and BTCP (Panel C) and then washed extensively by centrifugation as described in the Method section. The binding of $5 \mathrm{nM}\left[{ }^{3} \mathrm{H}\right] \mathrm{TCP}$ to site 1 and site 2 was measured. There was no significant effect on site 1 (data not shown). Each point is the mean $\pm \operatorname{SEM}(n=6) .{ }^{*} p<0.05$ when compared to control.

TABLE 6

POSSIBLE MECHANISMS FOR WASH RESISTANT INHIBITION

\begin{tabular}{lcccc}
\hline Mechanism & $K_{d}$ & $B_{\max }$ & Koff & $\begin{array}{c}\text { Inhibitory Activity } \\
\text { in Supernatant }\end{array}$ \\
\hline $\begin{array}{l}\text { 1. Residual drug in } \\
\text { the aqueous phase }\end{array}$ & $\Uparrow$ & $\mathrm{NC}$ & $\mathrm{NC}$ & Yes \\
$\begin{array}{l}\text { 2. Residual drug in } \\
\text { the membranes }\end{array}$ & $\Uparrow$ & $\mathrm{NC}$ & $\mathrm{NC}$ & No \\
$\begin{array}{l}\text { 3. Tight binder } \\
\text { 4. Pseudo allosteric }\end{array}$ & $\mathrm{NC}$ & $\Downarrow$ & $\mathrm{NC}$ & No \\
\hline
\end{tabular}

Four possible mechanisms to explain wash-resistant inhibition are shown along with the expected changes in the $K_{d}$ and $B_{\max }$ of the binding site, the dissociation rate of the $\left[{ }^{3} \mathrm{H}\right]$ ligand, and the inhibitory activity in the supernatant. The $\pi$ indicates an increase in value, $\alpha \Downarrow$ indicates a decrease, and $\mathrm{NC}$ indicates no change in the value. site producing a conformational change in the site labeled by the $\left[{ }^{3} \mathrm{H}\right]$ ligand (mechanism 4 ). This would typically produce an increase in the $K_{\mathrm{d}}$, without altering the $B_{\max }$. Because the increase in the $K_{\mathrm{d}}$ reflects a conformational change in the binding site, the dissociation rate of the $\left[{ }^{3} \mathrm{H}\right]$ ligand for that site would also be increased.

As described in Table 6, it is possible to distinguish these various models by measuring the effect of the wash-resistant inhibitor on (a) the residual drug in the aqueous phase, (b) the $B_{\max }$ and $K_{\mathrm{d}}$ of the target binding site, and (c) the dissociation rate of the $\left[{ }^{3} \mathrm{H}\right]$ ligand. To measure residual drug in the aqueous phase, membranes are centrifuged and the supernatant is assayed for inhibitory activity. Saturation binding studies permit determination of the $B_{\max }$ and $K_{\mathrm{d}}$ while dissociation studies permit measurement of the dissociation rate, $\mathbf{k}_{-1}$.

Guinea pig membranes were used to determine the mechanism of wash-resistant inhibition reported in Fig. 4, because $\left[{ }^{3} \mathrm{H}\right]$ TCP binding to PCP site 2 is more readily measured with guinea pig membranes. As shown in Fig. 5, after pretreatment with $5000 \mathrm{nM}$ BTCP, the level of $\left[{ }^{3} \mathrm{H}\right] \mathrm{TCP}$ binding to PCP site 2 was diminished by about $50 \%$, yet there was no detectable residual drug. Due to the poor signal, it was not possible to conduct saturation binding studies. Dissociation experiments (Table 7) demonstrated that pretreatment with BTCP increased the dissociation rate of $\left[{ }^{3} \mathrm{H}\right] \mathrm{TCP}$ at PCP site 2 . This observation is incompatible with the residual drug hypothesis, because residual drug would increase the apparent $K_{\mathrm{d}}$ by acting as a competitive inhibitor but not alter the intrinsic dissociation rate.

Although these data pertain only to BTCP, it is likely that the other reuptake inhibitors produce wash-resistant inhibition via similar mechanisms. These data collectively suggest that the reuptake inhibitors bind to a site from which they slowly dissociate (the serotonin and dopamine reuptake carriers) and as a result of this, the binding of $\left[{ }^{3} \mathrm{H}\right] \mathrm{TCP}$ to site 2 decreases and the dissociation rate increases. This explanation implies that PCP site 2 and high affinity binding sites for classic uptake inhibitors are linked. They might, for example, be overlapping binding sites on the transporter protein or allosterically linked but separate proteins. The observation that neither GBR12909 nor fluoxetine produced a complete washresistant inhibition of $\left[{ }^{3} \mathrm{H}\right] \mathrm{TCP}$ binding to site 2 suggests that in human cortex PCP site 2 may be a mixture of both serotonergic and dopaminergic reuptake carriers.

The observation that a wash-resistant inhibitor decreases $\left[{ }^{3} \mathrm{H}\right]$ ligand binding in the absence of supernatant inhibition and increases the dissociation rate of the $\left[{ }^{3} \mathrm{H}\right]$ ligand is compatible with what we have termed a pseudoallosteric model (mechanism 4 of Table 6). The observation of an increased dissociation rate could be taken as evidence for the occurrence of negative cooperativity. In this case, one would also expect to observe evidence of negative cooperativity in equilibrium binding studies, such as curvilinear Scatchard plots or low Hill coefficients. However, this is not the case for the interaction of $(+)$-cis-methylfentanyl with opioid mu receptors (63), the interaction of paroxetine with $\left[{ }^{3} \mathrm{H}\right]$ cocaine binding sites (1) or the interaction of (+)-MK-801 with PCP site 1 (37).

A fourth line of evidence that PCP site 2 is associated with the biogenic amine transporters comes from lesion studies (2). As reported in Table 8, that study showed that a greater than $95 \%$ lesion of the dopaminergic innervation of the caudate produced by MPTP resulted in about a 50\% decrease in PCP site 2 indicating that PCP site 2 is localized in part to the dopaminergic nerve terminal. 


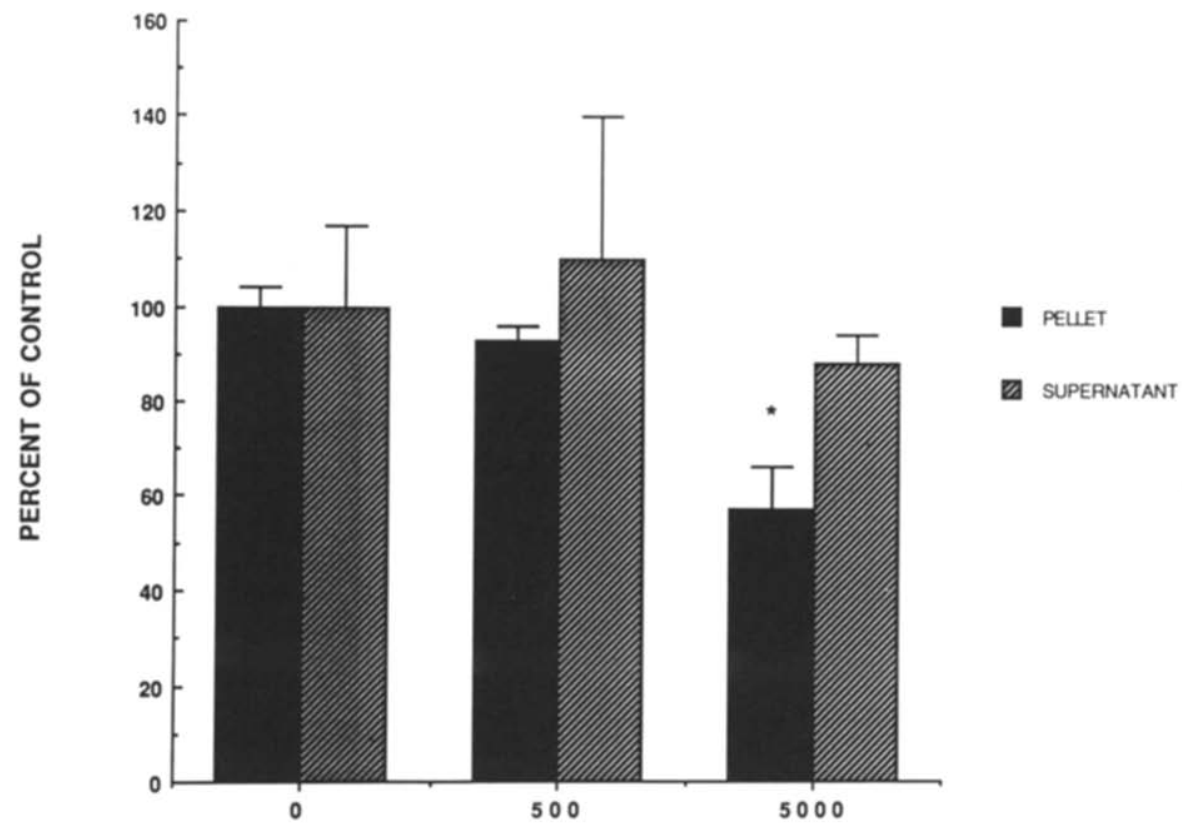

[BTCP] $\mathrm{nM}$

FIG. 5. Wash-resistant inhibition of $\left[{ }^{3} \mathrm{H}\right] \mathrm{TCP}$ binding to PCP site 2. As described in the Method section, guinea pig brain membranes were pretreated with the indicated doses of BTCP, washed extensively by centrifugation, and the pellets and supernatants assayed with $\left[{ }^{3} \mathrm{H}\right] \mathrm{TCP}$ as described in the Method section. Values represent mean \pm SEM of three membrane preparations each with triplicate observations $\left({ }^{*} p<0.05\right)$.

\section{CONCLUSIONS}

Phencyclidine and phencyclidine-like compounds produce various dose-dependent behavioral effects which are likely mediated through different molecular sites of actions. Single and multiple affinity PCP binding sites have been reported in the CNS. For example, Jarvis et al. (20), Vincent et al. (58), Zukin and Zukin (64), and Quirion et al. (34) reported the presence of a single high affinity binding site for $\left[{ }^{3} \mathrm{H}\right] \mathrm{TCP}$, which is now known to exist as a component of the NMDA/ionophore complex (62). Multiple PCP binding sites have also been reported in the rat $(17,18,28,53,56)$ as well as human brain tissue (53). Moreover, the data reviewed in this paper provide a compelling case for the existence of multiple $\left[{ }^{3} \mathrm{H}\right] \mathrm{TCP}$ binding sites. Unfortunately, there is currently insufficient ligand-selectivity data to permit an unambiguous identification of $P C P$ site 2 with the other low affinity PCP binding sites reported by other investigators [see the Discussion section in (41)].

Among the structurally diverse group of agents which act as noncompetitive NMDA antagonists, only PCP and its congeners of the arylcycloalkylamine group potently inhibit the reuptake of biogenic amines $(21,54)$. Indeed, a recent study (12) demonstrated a good correlation between inhibition of $\left[{ }^{3} \mathrm{H}\right] \mathrm{PCP}$ binding and inhibition of $\left[{ }^{3} \mathrm{H}\right] \mathrm{DA}$ reuptake only for arylcyclohexylamines bearing an unmodified phenyl group. Nevertheless, several lines of evidence support the hypothesis that the noncompetitive NMDA antagonist effect of PCP is sufficient to explain its pharmacological effects: (a) the selective noncompetitive NMDA antagonist $(+)-\mathrm{MK}-801$ produces the same behavioral effects as PCP in laboratory animals (25) yet it is a very weak reuptake blocker (47); (b) the anatomical distribution of $\left[{ }^{3} \mathrm{H}\right] \mathrm{TCP}$ binding sites in rat brain is almost identical to that of the NMDA receptor (20); (c) The general inability, as noted above, to detect $\left[{ }^{3} \mathrm{H}\right] \mathrm{TCP}$ binding sites in rat brain not associated with the NMDA receptor.

Other data indicate that more complex interpretations may be necessary to explain the behavioral and pharmacological

TABLE 7

DISSOCIATION OF $\left[{ }^{3} \mathrm{H}\right.$ ]TCP FROM PCP SITE 2 IN MEMBRANES PRETREATED WITH $5000 \mathrm{nM}$ BTCP

\begin{tabular}{lcc}
\hline & Control & Treated \\
\hline $\begin{array}{l}\text { One Component } \\
\left(\min ^{-1}\right)\end{array}$ & $0.002 \pm 0.0003$ & $0.004 \pm 0.001^{*}$ \\
\hline
\end{tabular}

These data are from (3). Guinea pig brain membranes were pretreated with 0 or $5000 \mathrm{nM}$ BTCP following a 3-h incubation with $5 \mathrm{nM}\left[{ }^{3} \mathrm{H}\right] \mathrm{TCP}$ in the presence of $500 \mathrm{nM}(+)-\mathrm{MK}-801$ (to block binding to site 1), $10 \mu \mathrm{M}$ TCP was added to block the association of $\left[{ }^{3} \mathrm{H}\right] \mathrm{TCP}$ with PCP site 2 , and aliquots were subsequently filtered at various time points. The dissociation rate constant, $k_{-1}$, was determined by fitting the dissociation data to the equation describing a single component dissociation model. Data represent mean \pm SEM for three experiments each with triplicate observations. ${ }^{*} p<0.05$ when compared to control. 
TABLE 8

EFFECT OF MPTP AND RESERPINE ON DA LEVELS, SEROTONIN LEVELS, $\left[{ }^{3} \mathrm{H}\right] \mathrm{TCP}$, AND [ $\left.{ }^{3} \mathrm{H}\right] \mathrm{GBR} 12935$ BINDING SITES IN DOG CAUDATE

\begin{tabular}{|c|c|c|c|c|c|}
\hline \multirow[b]{2}{*}{ Group } & \multicolumn{2}{|c|}{$\left[{ }^{3} \mathrm{H}\right] \mathrm{TCP}$} & \multirow[b]{2}{*}[{}^{3}\mathrm{H}]{$\mathrm{GBR} 12935$} & \multirow[b]{2}{*}{ DA } & \multirow[b]{2}{*}{ Serotonin } \\
\hline & Site 1 & Site 2 & & & \\
\hline Control & $143 \pm 8$ & $24 \pm 5.4$ & $5010 \pm 429$ & $95.6 \pm 3.8$ & $2.7 \pm 0.5$ \\
\hline MPTP & $195 \pm 28$ & $13.9 \pm 5.2^{*}$ & $521 \pm 35^{*}$ & $0.3 \pm 0.03^{*}$ & $4.6 \pm 1.0$ \\
\hline Reserpine & $117 \pm 2^{*}$ & $25.4 \pm 2.6$ & $5846 \pm 394$ & $5.1 \pm 1.0^{*}$ & $1.7 \pm 0.4 \dagger$ \\
\hline
\end{tabular}

These data are from (2). Female hounds were treated with saline, MPTP, or reserpine for an unrelated study. Otherwise unused caudate tissue was assayed for DA (pg/ $/ \mu \mathrm{g}$ protein), serotonin (pg/ $\mu \mathrm{g}$ protein), and $\left[{ }^{3} \mathrm{H}\right] \mathrm{TCP}$ and $\left[{ }^{3} \mathrm{H}\right] \mathrm{GBR} 12935$ binding sites ( $\mathrm{fmol} / \mathrm{mg}$ protein). Each value is the mean $\pm \operatorname{SEM}(n=3$ or 4$) .{ }^{*} p<0.05$ when compared to control. $t p<0.05$ when compared to the MPTP group.

effects of PCP. For example, animals trained to discriminate PCP from saline do not completely generalize to competitive NMDA antagonists $(19,61)$. Rhesus monkeys with a recent history of exposure to cocaine will not learn to self-administer MK-801 (9), though rhesus monkeys readily learn to self-administer PCP. Because MK-801 does not inhibit DA reuptake (47), these data suggest that the DA reuptake blocking effects of PCP may contribute to its reinforcing effects. In addition, effects of PCP that can be ascribed to reuptake blockade such as hypothermia (32), decrease of prolactin levels $(30,31)$, and elevation of extracellular levels of DA (11) as measured by in vivo microdialysis occur in the same dose range as effects of PCP which can be ascribed to antagonism of the NMDA receptor, such as its anticonvulsant (26) and neuroprotective (43) effects. The recent work by Rao et al. (35) also support the notion that pharmacologically relevant effects of PCP occur via activation of nonNMDA associated PCP receptors.

These data collectively support the hypothesis that the interaction of PCP with nonNMDA receptor associated receptors, such as the biogenic amine transporters, play an important role in the reinforcing effects of PCP, as well in certain other pharmacological effects of PCP. The data reviewed in the previous sections support the sentiment that PCP site 2 might be a binding site for the physiologically relevant nonNMDA PCP receptor referred to above. The high degree of selectivity of biogenic amine transporter ligands for PCP site 2 , their pseudoallosteric interaction with PCP site 2 , and the association of PCP site 2 with dopaminergic nerve terminals all support the association between PCP site 2 and biogenic amine transporters. However, the generally low potency with which the transporter ligands bind to PCP site 2 argues against this association. Although the selective interaction of the $\mathrm{K}^{+}$ channel blocker TEA with PCP site 2 might simply reflect similarities between two PCP receptors, i.e., the $\mathrm{K}^{+}$channel and the biogenic amine transporter, it is also possible that PCP site 2 is actually a mix of various nonNMDA-receptor-associated PCP binding sites. This notion is supported by the similar affinity of selective 5-HT (fluoxetine), DA (GBR12909, bupropion), and NE (desipramine, xylamine) uptake inhibitors for PCP site 2 (See Table 1).

The recent demonstration that a single cDNA expresses a monomeric membrane protein which possesses both the DA transport function and a binding site for uptake inhibitors such as cocaine $(22,45)$ now makes it possible to test the hypothesis that PCP site 2 is a binding site on the DA transporter protein. According to this hypothesis, COS cells transiently expressing the DA transporter should also express a binding site with the characteristics of PCP site 2. If this is indeed shown to be the case, then our data lead us to speculate that the binding sites for classic uptake inhibitors such as cocaine will comprise a different domain then the binding domain for PCP site 2 ligands. This notion can be directly tested using mutant DA transporters (23). These types of experiments can also be done using cDNAs which encode the 5-HT and NE transporters $(10,29)$.

The strong likelihood that PCP site 2 is actually a heterogeneous mixture of binding sites suggests that very little additional information is likely to come from the study of PCP site 2 using ligand binding methods. Future studies, which will depend on the development of ligands selective for PCP site 2 , must address the identity of these binding sites with biochemical and molecular biological methods.

\section{REFERENCES}

1. Akunne, H. C.; de Costa, B. R.; Jacobson, A. E.; Rice, K. C.; Rothman, R. B. $\left[{ }^{3} \mathrm{H}\right]$ Cocaine labels a binding site associated with the serotonin transporter in guinea pig brain: Allosteric modulation by paroxetine. Neurochem. Res. 17:1275-1283; 1992.

2. Akunne, H. C.; Johannessen, J. N.; de Costa, B. R.; Rice, K. C.; Rothman, R. B. MPTP lesions of the nigrostriatal dopaminergic projection decrease $\left[{ }^{3} \mathrm{H}\right] 1-[1-(2-$ thienyl)cyclohexyl]piperidine binding to PCP site 2: Further evidence that PCP site 2 is associated with the biogenic amine reuptake complex. Neurochem. Res. 17: 261-264; 1992.

3. Akunne, H. C.; Reid, A. A.; Thurkauf, A.; Jacobson, A. E.; de Costa, B. R.; Rice, K. C.; Heyes, M. P.; Rothman, R. B. $\left[{ }^{3} \mathrm{H}\right] 1-[1-(2-$ thienyl)cyclohexyl]piperidine labels two high affinity binding sites in human cortex: further evidence for phencyclidine binding sites associated with the biogenic amine reuptake complex. Synapse 8:289-300; 1991.

4. Albuquerque, E. X.; Tsai, M. C.; Aronstam, R. S.; Witkop, B.; Eldefrawi, A. T.; Eldefrawi, M. E. Phencyclidine interactions with the ionic channel of the acetylcholine receptor and electrogenic membrane. Proc. Natl. Acad. Sci. USA 77:1224-1228; 1980.

5. Anis, N. A.; Berry, S. C.; Burton, N. R.; Lodge, D. The dissociative anaesthetics, ketamine and phencyclidine, selectively reduce excitation of central mammalian neurons by $N$-methyl-aspartate. Br. J. Pharmacol. 79:565-575; 1983.

6. Aronstam, R. S.; Eldefrawi, M. E.; Eldefrawi, A. T.; Albuquer- 
que, E. X.; Jim, K. F.; Triggle, D. J. Sites of action of phencyclidine. III. Interactions with muscarinic receptors. Mol. Pharmacol. 18:179-184; 1980.

7. Bartschat, D. K.; Blaustein, M. P. Phencyclidine in low doses selectively blocks a presynaptic voltage-regulated potassium channel in rat brain. Proc. Natl. Acad. Sci. USA 83:189-192; 1986.

8. Bartschat, D. K.; Blaustein, M. P. Psychotomimetic sigmaligands, dexoxadrol and phencyclidine block the same presynaptic potassium channel in rat brain. J. Physiol. (Lond) 403:341-353; 1988.

9. Beardsley, P. M.; Hayes, B. A.; Balster, R. L. The self-administration of MK-801 can depend upon drug-reinforcement history, and its discriminative stimulus properties are phencyclidinelike in rhesus monkeys. J. Pharmacol. Exp. Ther. 252:953-959; 1990.

10. Blakely, R. D.; Berson, H.; Fremean, R. T. Jr.; Caron, M. G.; Peek, M. M.; Prince, H. K.; Bradley, C. C. Cloning and expression of a functional serotonin transporter from rat brain. Nature 354:66-70; 1991.

11. Carboni, E.; Imperato, A.; Perezzani, L.; Di Chiara, G. Amphetamine, cocaine, phencyclidine and nomifensine increase extracellular dopamine concentrations preferentially in the nucleus accumbens of freely moving rats. Neuroscience $28: 653-661 ; 1989$.

12. Chaudieu, I.; Vignon, J.; Chicheportiche, M.; Kamenka, J. M.; Trouiller, G.; Chicheportiche, R. Role of the aromatic group in the inhibition of phencyclidine binding and dopamine uptake by PCP analogs. Pharmacol. Biochem. Behav. 32:699-705; 1989.

13. Chicheportiche, R.; Agid, Y.; Chaudieu, I.; Gusdinar, T.; JavoyAgid, F.; Journet, L.; Kamenka, J. M.; Vignon, J. The multiple binding sites of $\left[{ }^{3} \mathrm{H}\right] \mathrm{PCP}$ and $\left[{ }^{3} \mathrm{H}\right] \mathrm{TCP}$ in the rat and human CNS. In: Domino, E. F.; Kamenka, J. M., eds. Sigma and phencyclidine-like compounds as molecular probes in biology. Ann Arbor, MI: NPP Books; 1988:107-116.

14. Cook, N. S.; Quast, U. Potassium channel pharmacology. In: Cook, N. S., ed. Potassium channels: Structure, classification, function and therapeutic potential. Chichester: Ellis Harwood Limited; 1990:151-155.

15. Cotman, C. W.; Iversen, L. L. Excitatory amino acids in the brain - Focus on NMDA receptors. Trends Neurosci. 10:263-265; 1987.

16. ffrench-Mullen, J. M.; Rogawski, M. A. Interaction of phencyclidine with voltage-dependent potassium channels in cultured rat hippocampal neurons: Comparison with block of the NMDA receptor-ionophore complex. J. Neurosci. 9:4051-4061; 1989.

17. Haring, R.; Kloog, Y.; Kalir, A.; Sokolovsky, M. Binding studies and photoaffinity labeling identify two classes of phencyclidine receptors in rat brain. Biochemistry 26:5854-5861; 1987.

18. Itzhak, $Y .\left[^{3} \mathrm{H}\right] \mathrm{PCP}-3-\mathrm{OH}$ and $(+)\left[{ }^{3} \mathrm{H}\right] \mathrm{SKF} 10047$ bind to multiple sigma/opiate/PCP binding sites in rat brain. In: Domino, E. F.; Kamenka, J. M., eds. Sigma and phencyclidine-like compounds as molecular probes in biology. Ann Arbor, MI: NPP Books; 1988:129-138.

19. Jackson, A.; Sanger, D. J. Is the discriminative stimulus produced by phencyclidine due to an interaction with $N$-methyl-D-aspartate receptors. Psychopharmacology (Berlin) 96:87-92; 1988.

20. Jarvis, M. F.; Murphy, D. E.; Williams, M. Quantitative autoradiographic localization of NMDA receptors in rat brain using $\left[{ }^{3} \mathrm{H}\right] \mathrm{CPP}$ : comparison with $\left[{ }^{3} \mathrm{H}\right] \mathrm{TCP}$ binding sites. Eur. J. Pharmacol. 141:149-152; 1987.

21. Johnson, K. M.; Snell, L. D. Effects of phencyclidine (PCP)-like drugs on turning behavior, $\left[{ }^{3} \mathrm{H}\right]$-dopamine uptake, and $\left[{ }^{3} \mathrm{H}\right]-\mathrm{PCP}$ binding. Pharmacol. Biochem. Behav. 22:731-735; 1985.

22. Kilty, J. E.; Lorang, D.; Amara, S. G. Cloning and expression of a cocaine-sensitive rat dopamine transporter. Science 254:578$579 ; 1991$.

23. Kitayama, S.; Shimada, S.; Xu, H.; Markham, L.; Donovan, D. M.; Uhl, G. R. Dopamine transporter site-directed mutations differentially alter substrate transport and cocaine binding. Proc. Natl. Acad. Sci. USA 89:7782-7785; 1992.

24. Koek, W.; Woods, J. H. Assessing directly observable behavioral effects of phencyclidine (PCP)-like drugs in pigeons, in rats, and in rhesus monkeys. In: Domino, E. F.; Kamenka, J. M., eds.
Sigma and phencyclidine-like compounds as molecular probes in biology. Ann Arbor, MI: NPP Books; 1988:493-509.

25. Koek, W.; Woods, J. H. Correlations between phencyclidine-like activity and $N$-methyl-D-aspartate antagonism: behavioral evidence. In: Domino, E. F.; Kamenka, J. M., eds. Sigma and Phencyclidine-like compounds as molecular probes in biology. Ann Arbor, MI: NPP Books; 1988:357-372.

26. Leander, J. D.; Rathbun, R. C.; Zimmerman, D. M. Anticonvulsant effects of phencyclidine-like drugs: Relation to $N$-methyl-Daspartic acid antagonism. Brain Res. 454:368-372; 1988.

27. Loo, P. S.; Braunwalder, A. F.; Lehmann, J.; Williams, M. Sills, M. A. Interaction of L-glutamate and magnesium with phencyclidine recognition sites in rat brain: evidence for multiple affinity states of the phencyclidine $/ N$-methyl-D-aspartate receptor complex. Mol. Pharmacol. 32:820-830; 1987.

28. Mendelsohn, L. G.; Kerchner, G. A.; Kalra, V.; Zimmerman, D. M.; Leander, J. D. Phencyclidine receptors in rat brain cortex. Biochem. Pharmacol. 33:3529-3535; 1984.

29. Pacholczyk, T.; Blakely, R. D.; Amara, S. G. Expression cloning of a cocaine- and antidepressant-sensitive human noradrenaline transporter. Nature 350:350-354; 1991.

30. Pechnick, R. N.; George, R.; Poland, R. E. Characterization of the effects of the acute and repeated administration of MK-801 on the release of adrenocorticotropin, corticosterone and prolactin in the rat. Eur. J. Pharmacol. 164:257-263; 1989.

31. Pechnick, R. N.; George, R.; Poland, R. E.; Hiramatsu, M.; Cho, A. K. Characterization of the effects of acute and chronic administration of phencyclidine on the release of adrenocorticotropin, corticosterone and prolactin in the rat: Evidence for the differential development of tolerance. J. Pharmacol. Exp. Ther. 250:534-540; 1989 .

32. Pechnick, R. N.; Wong, C. A.; George, R.; Thurkauf, A.; Jacobson, A. E.; Rice, K. C. Comparison of the effects of the acute administration of dexoxadrol, levoxadrol, MK-801 and phencyclidine on body temperature in the rat. Neuropharmacology 28:829$835 ; 1989$.

33. Politi, D. M. T.; Rogawski, M. A. Glyburide-sensitive $\mathrm{K}^{+}$channels in cultured rat hippocampal neurons: Activation by cromakalim and energy-depleting conditions. Mol. Pharmacol. 40:308$315 ; 1991$.

34. Quirion, R.; Hammer, R. P.; Herkenham, M.; Pert, C. B. Phencyclidine (angel dust)/sigma "opiate" receptor: Visualization by tritium-sensitive film. Proc. Natl. Acad. Sci. USA 78:5881-5885; 1981.

35. Rao, T. S.; Kim, H. S.; Lehmann, J.; Martin, L. L.; Wood, P. L. Selective activation of dopaminergic pathways in the mesocortex by compounds that act at the phencyclidine (PCP) binding site: tentative evidence for PCP recognition sites not coupled to $N$-methyl-D-aspartate (NMDA) receptors. Neuropharmacology 29:225-230; 1990.

36. Reid, A. A.; Mattson, M. V.; de Costa, B. R.; Thurkauf, A.; Jacobson, A. E.; Monn, J. A.; Rice, K. C.; Rothman, R. B. Specificity of phencyclidine-like drugs and benzomorphan opiates for NMDA-coupled and dopamine uptake carrier associated phencyclidine binding sites in guinea pig brain. Neuropharmacology 29:811-817; 1990 .

37. Reid, A. A.; Monn, J. A.; Jacobson, A. E.; Rice, K. C.; Rothman, R. B. Pseudoallosteric modulation by $(+)-\mathrm{MK}-801$ of NMDA-coupled phencyclidine binding sites. Life Sci. 47:PL77PL82; 1990.

38. Rogawski, M. A. The A-current: How ubiquitious a feature of excitable cells is it? Trends Neurosci. 8:214-219; 1991.

39. Rothman, R. B. Binding surface analysis: An intuitive yet quantitative method for the design and analysis of ligand binding studies. Alcohol. Drug Res. 6:309-325; 1986.

40. Rothman, R. B.; Reid, A. A.; Kim, A.; Ni, Q.; de Costa, B. R.; Rice, K. C.; Bowen, W. D. The competitive NMDA receptor antagonist, CPP, allosterically modulates the NMDA receptor associated phencyclidine binding site in the apparent absence of steric hindrance. In: Domino, E. F.; Kamenka, J. -M., eds. Multiple sigma and PCP receptor ligands: Mechanisms for neuromodulation and neuroprotection. Ann Arbor, MI: NPP Books; 1992:307-330. 
41. Rothman, R. B.; Reid, A. A.; Monn, J. A.; Jacobson, A. E.; Rice, K. C. The psychotomimetic drug phencyclidine labels two high affinity binding sites in guinea pig brain: Evidence for $N$-methyl-D-aspartate-coupled and dopamine reuptake carrierassociated phencyclidine binding sites. Mol. Pharmacol. 36:887896; 1989.

42. Rothman, R. B.; Reid, A. A.; Silverthorn, M.; de Costa, B. R.; Monn, J. A.; Thurkauf, A.; Jacobson, A. E.; Rice, K. C.; Rogawski, M. A. Structure-activity studies on the interaction of biogenic amine reuptake inhibitors and potassium channel blockers with MK-801-sensitive (PCP site 1) and -insensitive (PCP site 2) $\left[{ }^{3} \mathrm{H}\right] \mathrm{TCP}$ binding sites in guinea pig brain. In: Domino, E. F.; Kamenka, J. -M., eds. Multiple sigma and PCP receptor ligands: Mechanisms for neuromodulation and neuroprotection. Ann Arbor, MI: NPP Books; 1992:137-146.

43. Sauer, D.; Nuglisch, J.; Rossberg, C.; Mennel, H. D.; Beck, T.; Bielenberg, G. W.; Krieglstein, J. Phencyclidine reduces postischemic neuronal necrosis in rat hippocampus without changing blood flow. Neurosci. Lett. 91:327-332; 1988.

44. Segal, M.; Rogawski, M. A.; Barker, J. L. A transient potassium conductance depresses the excitability of cultured rat hippocampal and spinal neurons. J. Neurosci. 4:604-609; 1984.

45. Shimada, S.; Kitayama, S.; Lin, C. -L.; Patel, A.; Nanthakumar, E.; Gregor, P.; Kuhar, M.; Uhl, G. Cloning and expression of a cocaine-sensitive dopamine transporter complementary DNA. Science 254:576-578; 1991.

46. Smith, R. C.; Meltzer, H. Y.; Arora, R. C.; Davis, J. M. Effects of phencyclidine on $\left[{ }^{3} \mathrm{H}\right]$ catecholamine and $\left[{ }^{3} \mathrm{H}\right]$ serotonin uptake in synaptosomal preparations from rat brain. Biochem. Pharmacol. 26:1435-1439; 1977.

47. Snell, L. D.; Yi, S. J.; Johnson, K. M. Comparisons of the effects of MK-801 and phencyclidine on catecholamine uptake and NMDA-induced norepinephrine release. Eur. J. Pharmacol. 145: 223-226; 1988.

48. Sonders, M. S.; Keana, J. F. W.; Weber, E. Phencyclidine and psychotomimetic sigma opiates: Recent insights into their biochemical and physiological sites of action. Trends Neurosci. 11: 37-40; 1988.

49. Spruce, A. E.; Standen, N. B.; Stanfield, P. R. The action of external tetraethylammonium ions on initary delayed rectifier potassium channels of frog skeletal muscle. J. Physiol. (Lond) 393: $467-478 ; 1987$.

50. Stanfield, P. R. Tetraethylammonium ions and the potassium permeability of excitable cells. Rev. Physiol. Biochem. Pharmacol. 97:1-67; 1983.

51. Tang, A. H.; Collins, R. J. Behavioral effects of a novel kappa opioid analgesic, U-50488, in rats and rhesus monkeys. Psychopharmacology. (Berlin) 85:309-314; 1985.

52. Thurkauf, A.; de Costa, B.; Yamaguchi, S.; Mattson, M. V.; Jacobson, A. E.; Rice, K. C.; Rogawski, M. A. Synthesis and anticonvulsant activity of 1-phenylcyclohexylamine analogues. J. Med. Chem. 33:1452-1458; 1990.
53. Vignon, J.; Chaudieu, I.; Allaoua, H.; Journod, L.; Javoy-Agid, F.; Agid, Y.; Chicheportiche, R. Comparison of $\left[{ }^{3} \mathrm{H}\right]$ phencyclidine $\left(\left[{ }^{3} \mathrm{H}\right] \mathrm{PCP}\right)$ and $\left[{ }^{3} \mathrm{H}\right] \mathrm{N}-[1-(2$-thienyl)cyclohexyl]piperidine $\left.\left({ }^{3} \mathrm{H}\right] \mathrm{TCP}\right)$ binding properties to rat and human brain membranes. Life Sci. 45:2547-2555; 1989.

54. Vignon, J.; Lazdunski, M. Structure-function relationships in the inhibition of synaptosomal dopamine uptake by phencyclidine and analogues: Potential correlation with binding site identified with $\left[{ }^{3} \mathrm{H}\right]$ phencyclidine. Biochem. Pharmacol. 33:700-702; 1984.

55. Vignon, J.; Pinet, V.; Cerruti, C.; Kamenka, J-M.; Chicheportiche, R. $\left[{ }^{3} \mathrm{H}\right]-[1-(2-$-benzo[b]thiophenyl)cyclohexyl]piperidine ( ${ }^{3} \mathrm{H}$ BTCP): A new phencyclidine analog selective for the dopamine uptake complex. Eur. J. Pharmacol. 148:427-436; 1988.

56. Vignon, J.; Privat, A.; Chaudieu, I.; Thierry, A.; Kamenka, J. -M.; Chicheportiche, R. [ [ $\mathrm{H}]$ Thienyl-phencyclidine $\left.\left({ }^{3} \mathrm{H}\right] \mathrm{TCP}\right)$ binds to two different sites in rat brain. Localization by autoradiographic and biochemical techniques. Brain Res. 378:133-141; 1986.

57. Vignon, J.; Vincent, J. P.; Bidard, J. N.; Kamenka, J. M.; Geneste, P.; Monier, S.; Lazdunski, M. Biochemical properties of the brain phencyclidine receptor. Eur. J. Pharmacol. 81:531-542; 1982.

58. Vincent, J. P.; Kartalovski, B.; Geneste, P.; Kamenka, J. M.; Lazdunski, M. Interaction of phencyclidine ("angel dust") with a specific receptor in rat brain membranes. Proc. Natl. Acad. Sci. USA 76:4678-4682; 1979.

59. Weber, E.; Sonders, M.; Quarum, M.; McLean, S.; Pou, S.; Keana, J. F. 1,3-Di(2-[5- $\left.{ }^{3} \mathrm{H}\right]$ tolyl)guanidine: A selective ligand that labels sigma-type receptors for psychotomimetic opiates and antipsychotic drugs. Proc. Natl. Acad. Sci. USA 83:8784-8788; 1986.

60. Werkman, T. R.; Kawamura, T.; Yokoyama, S.; Higashida, H.; Rogawski, M. A. Peptide toxin block of $\mathrm{K}^{+}$channels expressed in fibroblast cells stably transfected with NGKl gene: Comparison with conventional $\mathrm{K}^{+}$channel antagonists. Soc. Neurosci. Abstracts 17:775; 1991.

61. Willets, J.; Balster, R. L. Phencyclidine-like discriminative stimulus properties of MK-801 in rats. Eur. J. Pharmacol. 146:167$169 ; 1988$.

62. Wood, P. L.; Rao, T. S.; Iyengar, S.; Lanthorn, T.; Monahan, J.; Cordi, A.; Sun, E.; Vazquez, M.; Gray, N.; Contreras, P. A review of the in vitro and in vivo neurochemical characterization of the NMDA/PCP/glycine/ion channel receptor macrocomplex. Neurochem. Res. 15:217-230; 1990.

63. Xu, H.; Kim, C.-H.; Zhu, Y. C.; Weber, R. J.; Rice, K. C.; Rothman, R. B. (+)-cis-Methylfentanyl and its analogs bind pseudoirreversibly to the mu opioid binding site: Evidence for pseudoallosteric modulation. Neuropharmacology 30:455-462; 1991.

64. Zukin, S. R.; Zukin, R. S. Specific $\left[{ }^{3} \mathrm{H}\right]$-phencyclidine binding in rat central nervous system. Proc. Natl. Acad. Sci. USA 76:5372$5376 ; 1979$. 